Rev. Tadeusz Zadykowicz John Paul II Catholic University of Lublin DOI: 10.15290/rtk.2021.20.07

iD 0000-0002-1687-8286

\title{
Models of State Ethical Neutrality in Selected Areas of Social Life
}

Contemporary societies are increasingly pluralistic, even in terms of their values, ideals, and norms of behavior. What should the state and its institution's attitude be toward citizens who have different and sometimes contradictory views on moral issues? One proposition is the principle of neutrality, particularly in the most controversial areas. This article outlines the characteristics of basic models of ethical neutrality and their practical application in specific areas of social life. A critical assessment of the consequences of introducing this principle sheds light on the need to search for a different definition of the state's role in morality.

Key words: ethical neutrality, morality, family.

Contemporary social life has become increasingly pluralistic and includes a variety of views on moral values, ideals, principles, and ethical norms. In order for society today to function well, it is necessary to determine the state's relationship to its citizens' morality. Among the different approaches, the model of ethical neutrality seems to correspond best to the secular, modern state. The multiplicity of ethical views that citizens uphold today seems to support the idea that the state should remain completely neutral and leave morality up to the choice of the individual. However, is such neutrality possible? In order to answer this question, it is important to recall that neutrality can take different forms and, as experience demonstrates, can be both a positive and negative thing. Moreover, attempts to remain neutral in some areas of social life have already proven very difficult. What is neutrality? What models of neutrality exist? On what is state neutrality regarding marriage and family life, education, culture, law, 
politics, economics, medicine, and the media based? What are the true intentions of proponents of neutrality? And finally, what is the Roman Catholic Church's attitude toward neutrality?

\section{Models of Neutrality}

Neutrality (from the Latin word "neuter," meaning "neutral, neither one nor the other") means indifference, impartiality, non-preference, and non-interference in the affairs of others. ${ }^{1}$ It can apply to different

Moral Theology areas, including social, political, and religious life. An individual or an entire society can be neutral. In the latter case, being neutral means a group or institution's lack of any involvement for other individuals or societies' benefit. If this lack of involvement concerns defense or the promotion of certain norms or values, then it is called ethical neutrality. According to ethical neutrality, each person can choose to live the lifestyle that suits him. The state that is ethically neutral declares that it cannot recommend or prohibit certain lifestyles. Individual citizens decide whether something is good or bad.

In practice, the promotion of state ethical neutrality often corresponds with the rejection of the Christian religion and morality. As a result, different models of neutrality that have different ideas about the role of ethics in the public sphere have been developed. Some of these models refer to materialism and are based in atheism. Others try to define the framework for collaboration between state institutions, the Catholic Church, and other religious associations with regard to promoting certain attitudes and values. There are three basic models of worldview neutrality that reflect a broader relationship between the state and churches.

The American model of separation of church and state is based on the First Amendment of the United States Constitution. This amendment prohibits the federal government from establishing a state religion and limiting religious freedom. The American model also prohibits all state interference in the internal affairs of religious associations and ensures churches' complete independence from the state in managing their affairs. In the USA, churches are classified as institutions of higher public utility. ${ }^{2}$ Europe has not adopted this system.

\footnotetext{
1 See P. Borecki, "Państwo neutralne światopoglądowo - ujęcie komparatystyczne," Studia z Prawa Wyznaniowego 9 (2006): 75.

2 See M. Gołda-Sobczak, "Systemy relacji między państwem a kościołami i związkami wyznaniowymi," Środkowoeuropejskie Studia Polityczne, no. 1 (2008): 86-89.
} 
The (extremely liberal) system of hostile separation between church and state in the French constitution was formed in opposition to (and not cooperation with) traditional religions. In the French version, the church is not a legal personality and can function only as a religious association. Thus, religion is completely "privatized" in France, which limits citizens' expression of their religious beliefs as much as possible. For example, in France, where this system arose, it is still prohibited to teach religion in public schools. According to this model of neutrality, all religious instruction has been removed from school curricula programs, religious values have been removed from education, and religion is treated as a manifestation of intellectual underdevelopment. This mode was introduced into schools in France in the nineteenth and twentieth centuries. In reality, this is not actual neutrality, but rather the depreciation of one worldview in favor of another. Currently, this radical stance on religion has been waning.

The third model, known as the coordinated separation system, the open system, or the German model, was determined based on open dialogue between the state and the dominant Christian sects in Germany. This model features a functional and institutional symbiosis between state structures and traditional religions. The model was established under the provisions of the Weimar Constitution of 1919, which explicitly states that Germany has no official state church, but that it recognizes and ensures religious freedom as a fundamental human right. Unlike in France, the churches have legal personality in Germany. Each church, therefore, can decide on its activities within the state. In addition, churches can collaborate with the state to address and resolve all types of issues. ${ }^{3}$ This system is prevalent in Europe. ${ }^{4}$

An analysis of the constitutional regulations of contemporary European countries shows that these countries use the following models in order to resolve the issue at hand: a religious state,${ }^{5}$ a secular state that is neutral by remaining closed to religious values (radically secular), as well as a secular state where neutrality is open (moderately secular). In light of these distinctions, two concepts are often mistakenly used interchangeably: "neutrality" and "secularism." A state with a

3 See T. Kamiński, "Relacje państwo-Kościół w obszarze usług socjalnych na przykładzie Stanów Zjednoczonych, Francji i Niemiec,” Nurt SVD 2 (2017): $365-368$.

$4 \quad$ See K. Orzeszyna, "Neutralność wyznaniowa," in Encyklopedia Katolicka, vol. 13, 965-966.

$5 \quad$ P. Borecki describes the different features and versions of a religious state. See "Znamiona państwa wyznaniowego. Uwagi na kanwie dorobku współczesnego konstytucjonalizmu," Studia Prawa Publicznego (2018): 33-53. 
Moral Theology

neutral worldview does not promote a particular religion or worldview. Such a state does not value religions but it treats them all equally. The public forum is open to any religion or religious symbolism. A state with a neutral worldview has a liberal (in the most universal sense of the word) attitude toward religion. In a state that has a neutral worldview, every person can practice whichever religion he pleases, be it agnosticism or atheism. No one can pressure, command, or prohibit others to profess or denounce a certain worldview. National axiology in this type of state is the subject of a living tradition that is continually enriched as it works toward social harmony. The United States of America, Germany, and Great Britain are examples of states with neutral worldviews.

The secular state, on the other hand, removes all manifestations of religiosity from the public sphere. The difference between a secular and atheistic state is essentially quantitative, not qualitative. The atheistic state seeks to remove religion from the private realm of its citizens. The secular state, however, does not think that religious worship should take place at all within political, social, or public spaces. The secular state creates it own axiology based on currently accepted philosophical and social doctrines, which it imposes on its citizens. The same type of state also creates its own rituals and symbols based around the axiology that it has invented and imposed, and these rituals and symbols resemble religious rituals and symbols. France is an example of a secular state. ${ }^{6}$

The liberal model is currently the dominant model in the contemporary world. According to this model, morality should be forced onto citizens' private lives. This is especially true in the case of those who provide social services. Because of the social role that they play, these individuals are expected to uphold and promote the morals that the state and society propose within the public sphere. If such individuals have any of their own moral convictions, then they should keep these private, "leave" them at home, and be guided at work (hospital, school, office) by the requirements formulated by state institutions, since the state and the community are the ones that assign them to the specific roles that individuals must fulfill. In this spirit, the public servant (doctor, teacher, official) must change his moral convictions and support official social beliefs. ${ }^{7}$

$6 \quad$ See F. Szymanek, "Formy prawnej instytucjonalizacji rozdziału państwa i Kościoła," Studia z Prawa Wyznaniowego 11 (2008): 50-52.

$7 \quad$ See T. Biesaga, “Zagrożenia sumienia lekarza," Medycyna Praktyczna 7-8(2005): 20 . 
Within the liberal model, the state harbors a hidden desire to blur the lines between what is legal and what is moral. This is the reason why the liberal state seeks to push morality onto its citizens within their private lives. The reverse, however, is prohibited: individuals cannot impose their private beliefs in the public realm. No one can impose rules of conscience on the state and society. This is particularly true for those who perform social functions; they are expected to remain morally and religiously neutral.

Which model does Poland follow? What type of state is the Republic of Poland? The Constitution of the Republic of Poland states: "Churches and other religious organizations shall have equal rights. Moral Public authorities in the Republic of Poland shall be impartial in matters of personal conviction, whether religious or philosophical, or in relation to outlooks on life, and shall insure their freedom of expression within public life." "Article 53 states that "Freedom of conscience and religion shall be ensured to everyone," 9 and continues by stating,

Freedom of religion shall include the freedom to profess or to accept a religion by personal choice as well as to manifest such religion, either individually or collectively, publicly or privately, by worshipping, praying, participating in ceremonies, performing of rites, or teaching. Freedom of religion shall also include possession of sanctuaries and other places of worship for the satisfaction of the needs of believers as well as the right of individuals, wherever they may be, to benefit from religious services. ${ }^{10}$

Poland, therefore, is not a secular country. One cannot legitimately invoke the Polish Constitution to remove religion from the Polish people's social and public life. ${ }^{11}$ When speaking about Poland, it is also illegitimate to refer to its inclusion in the European Union (EU) and claim that it must follow so-called "European standards," because these standards simply do not exist. Within the EU there are countries that have chosen to follow the neutral model, while other countries have opted to follow the secular model. The countries that follow the secular model are in the minority. Poland follows the coordinated separation model. In Poland, both Christian and secular worldviews

8 The Constitution of the Republic of Poland, art. 25 in Dziennik Ustaw No. 73, Item 483, accessed September 30, 2021, https://www.sejm.gov.pl/prawo/konst/ angielski/kon1.htm.

$9 \quad$ Ibid, art. 25.1.

10 Ibid, art 25.2.

11 SeeJ.Szymanek, "Przepisy wyznaniowew KonstytucjiRP(uwagiporządkujące)," Studia z Prawa Wyznaniowego 14 (2011): 5-23. 
exist side by side; they affect social life significantly; and, more recently, the two worldviews have increasingly clashed.

\section{Areas of Neutrality}

The areas that appeal to ethical neutrality most often are: marriage and family life; raising and educating children (particularly, sex education); culture; law; ${ }^{12}$ politics; economics; ${ }^{13}$ medicine; and the media. All of these areas are presumably meant to be ethically neutral (i.e.,

Moral Theology to be independent of values, of the realm of moral good and evil, and especially of the Christian moral tradition).

The areas of life most affected by so-called neutrality are marriage and family, especially the "neutral" state's attitude toward life and education. Most recently, clauses pertaining to the protection of doctors' consciences have been called into question in the name of the state's "ethical neutrality" towards human life. While this clause permits physicians to defend themselves against state or patient interference to defend themselves against actions that they, in conscience, consider wrong or morally unacceptable (e.g., abortion, assisted suicide, euthanasia, eugenic selection, etc.), ${ }^{14}$ so-called neutral states have tried to force doctors to perform acts that violate their conscience. Conscience clauses are inconvenient to a so-called "neutral state" because they prevent doctors from submitting to the state and society. As a result, attempts are made to undermine this clause by, among other things, requiring physicians to be axiologically and morally neutral. When neutrality is understood in this way, doctors are forced to perform abortions because they would be considered biased if they refused to do so.

Another area where the state imposes itself in the name of ethical neutrality is education. This interference can be seen, for example, in proposals to remove religion from schools or limiting parents' influence on school curricula. ${ }^{15}$ State neutrality toward education-just as toward life-is an illusion. When religion is removed from schools and education, then some other anthropology or vision of man replaces it.

12 The assertion that the relationship between the law and morality is not necessary is one of the fundamental claims of positive law.

13 In economics neutrality would mean a lack unscrupulous behavior and moral principles.

14 See M. Gałązka, "Odmowa przerywania ciąży a klauzula sumienia lekarza," Studia z Prawa Wyznaniowego 16 (2013): 23-42.

15 See J. Falski, "Prawo do nauki a prawo rodziców do zapewnienia wychowania i nauczania zgodnie z ich przekonaniami w orzecznictwie Europejskiego Trybunału Praw Człowieka," Studia z Prawa Wyznaniowego 17 (2014): 151-172. 
Even if it were possible to remain completely impartial in this area, such neutrality would be a manifestation of a lack of responsibility. All environments in which education takes place must be concerned about the human development of children.

The internal contradictions of so-called "ethical neutrality" are perhaps most evident in certain sex education proposals. Proponents of permissive sex education claim that they do not have a position on moral values - that they avoid lecturing others. In reality, however, they impose their own hierarchy of values on others, inculcate children and adults with the principles that they uphold, and criticize (and sometimes even mock) the Christian vision of sex education. The greatest irony is that proponents of morally neutral sex education demand that parents, churches, etc. not impose their morality (especially any prohibitions) on students. This attitude, however, betrays none other than the "morality" that the proponents of ethical neutrality promote because they encourage children to follow morally illicit lifestyles. It is, therefore, absurd to call such sex education (or other education) neutral.

In today's world, the media is one of the primary and most influential educators. The media's impact on children and youth is more effective than the influence of parents or school, and it is for this reason that the media's approach to ethical issues is crucial. Of course, every modern medium declares that it is ideologically and ethically neutral. In reality, however, the media has largely become a tool in the hands of ideologues whose vision threatens the religious state. Their slogan about the state's ideological neutrality is only a cover for spreading a different worldview: secularism. By imposing secularism, the state breeds unjust discrimination: it deprives believers of the opportunity to present their arguments in the public square, while permitting nonbelievers to freely proclaim their views.

Economics is another area that affects family life. Needless to say, most people agree that an economy unguided by ethical principles forgets about man and that profit at all cost violates human rights. ${ }^{16}$ Equally common today, however, is a spirit of extreme economism, which upholds that the purpose of economic activity is to satisfy man's material needs without any consideration for human life as such. ${ }^{17}$ This economism (and even economicism) is manifested in the absolutization

16 Grzegorz Kołodko includes such a thesis in his work Wędrującyświat (Warszawa: 2008).

17 SeeA.Zadroga,Katolicka myślekonomiczno-społeczna wobecfundamentalnych założeń ekonomii głównego nurtu (Lublin: 2018), 112. 
Moral Theology

of economic expediency, ${ }^{18}$ which originates in the postulates of the ethical neutrality of the economy and economic activity. The effect of this approach is that only a certain social strata manage all material goods.

"Neutral" policies also have a negative impact on the family and social life as a whole. The Catholic Church appreciates democracy. At the same time, She warns, "a democracy without values easily turns into open or thinly disguised totalitarianism." 19 While it is true that political community life has its own autonomy, ${ }^{20}$ this autonomy cannot be synonymous with independence from moral principles. Politics devoid of morality lead to the degeneration of social life and to the violation of human dignity and rights. Such politics turn against the family as the most basic community. As St. Paul exhorted, any politics that are worthy of the name should genuinely serve man and society: "serve one another through love" (Gal 5:13), and "No one should seek his own advantage, but that of his neighbor" (1 Cor 10:24). An ethically neutral politician is certainly incapable of such service.

\section{Does an Ethically Neutral State Exist?}

Contemporary democracies claim that the state should be both ideologically and religiously neutral. In such democracies, everyone can supposedly choose the lifestyle that suits him. A democratic state allegedly does not promote or prohibit certain lifestyles. It is up to every citizen to determine what is good or bad. The aforementioned examples, however prove that neutrality is only a façade behind which lurk questionable moral principles. For this reason, it is necessary to remain skeptical about the creation and existence of so-called "ethically neutral" states.

A state is not ethically neutral if and when it seeks to replace marriage and family morality with its own laws; redefine marriage; pass legislation that is opposed to life; interfere in educating and raising children; and promote ideologies that are hostile to religion. In these

18 See T. Zadykowicz, "Czy ekonomia może obyć się bez etyki?," in Człowiek etyka-ekonomia, eds. R. Horodeński and E. Ozorowski (Białystok: 2001), 25.

John Paul II, Centesimus Annus [Encyclical] (Citta del Vaticano: Libreria Editrice Vaticana, 1991), sec. 46, accessed September 30, 2021, https:/www.vatican.va/ content/john-paul-ii/en/encyclicals/documents/hf_jp-ii_enc_01051991_centesimus-annus.html.

20 See Second Vatican Council, Gaudium et Spes [Constitution on the Church in the Modern World], sec. 36, accessed September 30, 2021, https:// www.vatican.va/archive/hist_councils/ii_vatican_council/documents/ vat-ii_const_19651207_gaudium-et-spes_en.html. 
situations, ethical neutrality is closer to atheistic secularism than to a democracy based on values.

A lack of neutrality, even in states that claim to be neutral, is evident in attitudes toward the conscience clause mentioned above. It is difficult to justify why the state considers proponents of abortion to be ethically neutral and those who oppose abortion not. The reason for this, however, is rather straightforward. The so-called "neutral state" is based on a hidden anthropology. Contrary to what the state claims, it ascribes to a specific understanding of man and promotes this understanding through issues such as when human life begins, the status of the embryo, the criteria for being human. Under the guise of neutrality, the state imposes its relativistic, situational, and often outright anti-Christian vision of morality on its citizens.

A lack of neutrality is also evident in the state's vision for education. Behind the state's claim that it behaves neutrally toward children by allowing them to develop spontaneously is an attitude of dangerous indifference hidden under the guise of respecting their personalities. Such indifference toward and exemption from fulfilling ones duty to children are unacceptable. Children need help in developing and maturing. The great richness of life resides in the heart of every child. Children, however, are unable to understand what is going on within them. It is, therefore, the responsibility of adults-parents, educators, and those who work in media-to help children discover this. In this regard, Pope John Paul II asks: Is not every child like little Samuel, who-as the Bible states-is unable to understand the divine call and asks his guide for help-the very guide who tells him at first: "II did not call you,' Eli answered. 'Go back to sleep"' (1 Sam 3:5-6). Calling to mind the obligations of parents and educators, the Pope indicates an alternative: "Now, shall we adopt this kind of attitude and smother the inspirations that impel the child to higher things? Shall we not rather help him to understand and respond, as the priest Eli eventually did with Samuel: 'If he calls you again, you shall say: Speak Lord, for your servant is listening' (ibid. 3:9)."21

In this day and age, so-called neutrality in schools is anything but indifferent. Proof of this can be found by the changes made to Poland's core curriculum Family Life Education classes in 2015. These alterations made it possible for unscrupulous ideological groups and those who represent the specific interests of sexual educators to influence

21 John Paul II, Message for the $13^{\text {th }}$ World Communications Day [Social Communications for the Development of the Child], accessed September 30, 2021, https:/ www.vatican.va/content/john-paul-ii/en/messages/communications/documents/ hf_jp-ii_mes_23051979_world-communications-day.html. 
Moral Theology

children. These changes confirm that, whether openly or not, education is also influenced by a specific worldview. The only solution to this problem is to clearly expose the worldview upon which schools base their programs. Education, as John Paul II reminds us, is never morally indifferent, even when attempts are made to proclaim that it is ethically or religiously "neutral." The manner in which children and youth are formed and educated inevitably reflects these values that influence their way of understanding others and society as a whole. For this reason, school curricula should be developed in accordance with the nature and dignity of the human person and with God's law in order to help young people "discern and seek the truth, accept its demands and limits of authentic freedom, and respect the right of others to do the same."22

Even in the realm of economics so-called "neutrality" and essentially extreme economism easily transform people into slaves to possessions and instant gratification; they see no other prospect than to multiply the goods that they have or continually replace them with other better ones. ${ }^{23}$ Individuals as well as entire environments, societies, or nations fall victim to the desire to dominate other individuals, environments, or societies. ${ }^{24}$ Economic competition and rivalry between nations and states contribute to even greater divisions, social inequalities, and disparities in wealth. The gap between the rich North and the backward impoverished South is expanding, and not only a third but also a fourth world is emerging. And all of this is happening because economics has abandoned ethics in the name of so-called "neutrality."

$* * *$

${ }^{22}$ See John Paul II, Message for the World Day of Peace ["If You Want Peace, Respect the Conscience of Every Person”], sec 3, accessed September 30, 2021, https://www.vatican.va/content/john-paul-ii/en/messages/peace/documents/ hf_jp-ii_mes_08121990_xxiv-world-day-for-peace.html.

23 See John Paul II, Sollicitudo Rei Socialis [Encyclical], sec. 28, accessed September 30, 2021, https://www.vatican.va/content/john-paul-ii/en/encyclicals/ documents/hf_jp-ii_enc_30121987_sollicitudo-rei-socialis.html.

24 See John Paul II, Dives in Misericordia [Encyclical], sec. 11, accessed September 30,2021, https://www.vatican.va/content/john-paul-ii/en/encyclicals/documents/ hf_jp-ii_enc_30111980_dives-in-misericordia.html. Seealso Francis, Video Message to Participants in the "The Economy of Francesco-Young People, A Commitment, the Future," November 21, 2020, accessed September 30, 2021, 2021, https:/www.vatican.va/content/francesco/en/messages/pont-messages/2020/ documents/papa-francesco_20201121_videomessaggio-economy-of-francesco. html. 
In principle "neutrality" with regard to how the state acts towards its citizens appears to be a good tool to order the relationship between individuals and communities within pluralistic societies. The application of this principle, however, is very problematic. Declared neutrality often veils hidden intentions and actions that are based on an anthropology and value system that is anything but neutral. Therefore, an open worldview and guarantee of religious freedom, especially in the areas of life indicated above, are better than neutrality.

\section{Bibliography}

1. Biesaga, T. "Zagrożenia sumienia lekarza." Medycyna Praktyczna 7-8 (2005): 18-21.

2. Borecki, P. "Państwo neutralne światopoglądowo - ujęcie komparatystyczne." Studia z Prawa Wyznaniowego 9 (2006): 75-99.

3. Borecki, P. "Znamiona państwa wyznaniowego. Uwagi na kanwie dorobku współczesnego konstytucjonalizmu." Studia Prawa Publicznego (2018): 33-53.

4. Cogiel, M. "Wychowanie przez katechezę szkolną w dobie transformacji." Ateneum Kapłańskie 133, no. 1 (1999): 35-45. Accessed December 30, 2020. http://web.diecezja.wloclawek.pl/Ateneum/cogiel_542.html.

5. Falski, J. "Prawo do nauki a prawo rodziców do zapewnienia wychowania i nauczania zgodnie z ich przekonaniami w orzecznictwie Europejskiego Trybunału Praw Człowieka." Studia z Prawa Wyznaniowego 17 (2014): 151-172.

6. Francis. Video Message to Participants in the "The Economy of Francesco-Young People, A Commitment, the Future." November 21, 2020. Accessed September 8, 2021. https://www.vatican.va/content/francesco/ en/messages/pont-messages/2020/documents/papa-francesco_20201121_ videomessaggio-economy-of-francesco.html.

7. Gałązka, M. "Odmowa przerywania ciąży a klauzula sumienia lekarza." Studia z Prawa Wyznaniowego 16 (2013): 23-42.

8. Gołda-Sobczak, M. "Systemy relacji między państwem a kościołami i związkami wyznaniowymi." Środkowoeuropejskie Studia Polityczne, no. 1 (2008): 61-110.

9. John Paul II. Centesimus Annus [Encyclical]. Accessed September 30, 2021. https://www.vatican.va/content/john-paul-ii/en/encyclicals/documents/hf_jp-ii_enc_01051991_centesimus-annus.html.

10. John Paul II. Dives in Misericordia [Encyclical]. Accessed September 30, 2021. https://www.vatican.va/content/john-paul-ii/en/encyclicals/documents/hf_jp-ii_enc_30111980_dives-in-misericordia.html.

11. John Paul II. Message for the $13^{\text {th }}$ World Communications Day ["Social Communications for the Development of the Child"]. Accessed September 30, 2021. https://www.vatican.va/content/john-paul-ii/en/messages/communications/documents/hf_jp-ii_mes_23051979_world-communicationsday.html. 
12. John Paul II. Message for the World Day of Peace ["If You Want Peace, Respect the Conscience of Every Person"]. Accessed September 30, 2021. https://www.vatican.va/content/john-paul-ii/en/messages/peace/documents/hf_jp-ii_mes_08121990_xxiv-world-day-for-peace.html.

13. John Paul II. Sollicitudo Rei Socialis [Encyclical]. Accessed September 30, 2021. https:/www.vatican.va/content/john-paul-ii/en/encyclicals/documents/hf_jp-ii_enc_30121987_sollicitudo-rei-socialis.html.

14. Kamiński, T. "Relacje państwo-Kościół w obszarze usług socjalnych na przykładzie Stanów Zjednoczonych, Francji i Niemiec." Nurt SVD 2 (2017): 354-370.

Moral Theology
15. Kołodko, G. Wędrujacy świat. Warszawa: 2008.

16. "The Constitution of the Republic of Poland," Art. 25. In Dziennik Ustaw No. 73, Item 483. Accessed September 30, 2021. https:/www.sejm.gov.pl/ prawo/konst/angielski/kon1.htm.

17. Orzeszyna, K. "Neutralność wyznaniowa." In Encyklopedia Katolicka Vol. 13. k. 965-966.

18. Second Vatican Council. Gaudium et Spes [Constitution on the Church in the Modern World]. Accessed September 30, 3031. https://www. vatican.va/archive/hist_councils/ii_vatican_council/documents/vatii_const_19651207_gaudium-et-spes_en.html.

19. Szymanek, F. "Formy prawnej instytucjonalizacji rozdziału państwa i Kościoła." Studia z Prawa Wyznaniowego 11 (2008): 47-85.

20. Szymanek, J. "Przepisy wyznaniowe w Konstytucji RP (uwagi porządkujące)." Studia z Prawa Wyznaniowego 14 (2011): 5-23.

21. Zadroga, A. Katolicka myśl ekonomiczno-społeczna wobec fundamentalnych założeń ekonomii głównego nurtu. Lublin: 2018.

22. Zadykowicz, T. "Czy ekonomia może obyć się bez etyki?" In Człowiek - etyka - ekonomia. Edited by R. Horodeński and E. Ozorowski, 19-37. Białystok: 2001. 